\title{
Nutrients Uptake in Shoots and Biomass Yields and Roots and Nutritive Value of Zuri Guinea Grass Inoculated with Plant Growth-promoting Bacteria
}

Geovana C. R. Sá, Mariangela Hungria, Caroline Lopes Monteiro Carvalho, Adônis Moreira, Marco Nogueira, Reges Heinrichs \& Cecílio Viega Soares Filho

To cite this article: Geovana C. R. Sá, Mariangela Hungria, Caroline Lopes Monteiro Carvalho, Adônis Moreira, Marco Nogueira, Reges Heinrichs \& Cecílio Viega Soares Filho (2019) Nutrients Uptake in Shoots and Biomass Yields and Roots and Nutritive Value of Zuri Guinea Grass Inoculated with Plant Growth-promoting Bacteria, Communications in Soil Science and Plant Analysis, 50:22, 2927-2940, DOI: 10.1080/00103624.2019.1689256

To link to this article: https://doi.org/10.1080/00103624.2019.1689256

Published online: 13 Nov 2019.

Submit your article to this journal \lceil

Џ Article views: 55

Q View related articles $\square$

View Crossmark data \ulcorner

Full Terms \& Conditions of access and use can be found at

https://www.tandfonline.com/action/journallnformation?journalCode=lcss20 


\title{
Nutrients Uptake in Shoots and Biomass Yields and Roots and Nutritive Value of Zuri Guinea Grass Inoculated with Plant Growth-promoting Bacteria
}

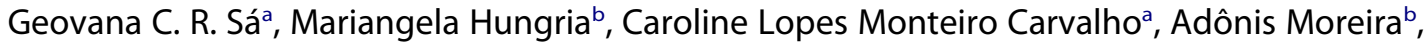 \\ Marco Nogueirab, Reges Heinrichs ${ }^{c}$, and Cecílio Viega Soares Filho ${ }^{a}$ \\ aDepartment of Production and Animal Health, São Paulo State University (UNESP), Araçatuba, São Paulo State, \\ Brazil; 'bepartment of Soil Science, Embrapa Soja, Londrina, Paraná State, Brazil; 'Department of Crop Science, São \\ Paulo State University (UNESP), Dracena, São Paulo State, Brazil
}

\begin{abstract}
The objective of this study was to evaluate the effects of plant growth promoting bacteria (PGPB) inoculation in Zuri guinea grass [Megathyrsus (syn. Panicum) maximus] on shoot dry weight (SDW) and root dry weight (RDW) yield, morphological compositions, number of tillers, and nutrients concentrations in SDW. The experiment was carried out under greenhouse conditions in a randomized block design consisting of eight treatments with five replicates. The inoculation with the Ab-V5 and Ab-V6 strains of Azospirillum brasilense and Pseudomonas fluorescens or co-inoculation with Rhizobium tropici and Ab-V6, with nitrogen (N) fertilization, as well as reinoculations of the plants after cuttings were taken were evaluated. The plant growth-promoting bacteria and $\mathrm{N}$ fertilization promoted increases in SDW and RDW yield, tillers dry weight, relative chlorophyll index $(\mathrm{RCI})$ and nutrients uptake in shoots of Zuri guinea grass. There were effects of reinoculation the PGPB by $P$. fluorescens in shoots, $N$, magnesium $(\mathrm{Mg})$ and boron (B) concentration in SDW.
\end{abstract}

\section{ARTICLE HISTORY}

Received 16 September 2019

Accepted 21 October 2019

\section{KEYWORDS}

Azospirillum brasilense; megathyrsus maximus; pseudomonas fluorescens; rhizobium tropici; tropical grass; nitrogen biological fixation; diazotrophic bacteria

\section{Introduction}

The edaphoclimatic conditions and the great territorial extension are factors that, since the beginning of the Brazilian livestock, define an important characteristic of this activity, to have almost the whole of the herd raised in pastures, which constitute in the most practical and economic way to produce and to feed the cattle (Sá et al. 2019; Teixeira et al. 2019).

Estimates indicate that Brazil has about 160 million hectares of pastures, of which, great deal of degradation is present. The causes of pasture degradation are due to absence or incorrect management of grazing, overcrowding of area, lack of replenishment of nutrients to the soil, inadequate fodder species for the crop region, presence of pests and invasive plants (Volpe et al. 2018).

Among the nutrients to increase pasture productivity, nitrogen $(\mathrm{N})$ is essential, especially in tropical regions. It is estimated that $\mathrm{N}$ fertilization generates a total cost of $40 \%$ of yield. In addition, this type fertilizer has great potential pollutant, being able to cause serious problems to environment (Hungria, Nogueira, and Araújo 2016). In this sense, using sustainable alternatives for plant nutrition, such as the exploration of the potential of the biological $\mathrm{N}$ fixation (BNF), becomes fundamental to increase the productivity of grasses. BNF is performed by diazotrophic bacteria, commonly known as plant growth promoting bacteria (PGPB) (Sá et al. 2019). 
The use of these microorganisms in forage plants is innovative because they can help in the sustainability of the system by reducing the probability of degradation of pastures, besides contributing to the increase in carbon (C) sequestration and, consequently, in greenhouse gases (Hungria, Nogueira, and Araújo 2016). BNF occurs from the transformation of atmospheric $\mathrm{N}_{2}$ into combined forms of $\mathrm{N}$, which are then assimilated by plants to form organic molecules (Hungria, Mendes, and Mercante 2013a). The benefits of PGPB have been attributed to a variety of unique or combined mechanisms that act in a cumulative or cascading manner (Bashan and De-Bashan 2010), including increased nutrient and water uptake (Ardakani et al. 2011). The production and secretion of phytohormones and other signaling molecules, such as auxins (Spaepen and Vanderleyden 2015), cytokinins (Tien, Gaskins, and Hubbell 1979), gibberellins (Bottini et al. 1989), salicylic acid (Sahoo et al. 2014) and phosphate solubilization (Rodriguez et al. 2004).

However, in spite of the benefits promoted by PGPB in agricultural crops, its effects on forage plants are still restricted and need studies, as already evidenced by Hungria, Nogueira, and Araújo (2013b). Aware of the concern to produce meat in a sustainable manner we observed the potential of the use of PGPB in forage plants, since the pastures comprise the main source of feed of the Brazilian herd. However, despite the benefits promoted by the bacteria inoculation in agricultural crops, their effects and responses in forage plants are still restricted and require studies (Sá et al. 2019).

In this sense, to evaluate the effects of these PGPB in forage plants on pasture development, it becomes fundamental in the search for economic and sustainable exploitation. Therefore, the objective of this study was to evaluate the effects of inoculation of PGPB in the development of 'Zuri' guinea grass on SDW and RDW yield and nutrients concentrations in SDW.

\section{Materials and methods}

\section{Local site and experimental design}

The experiments were conducted during spring under greenhouse conditions (average temperature of $26^{\circ} \mathrm{C}$ and photoperiod of $14 / 10 \mathrm{~h}$, day/night) in 8-liter plastic pots. The forage species Megathyrsus (syn. Panicum) maximus cv. BRS Zuri was cultivated at São Paulo State University (UNESP-FMVA)

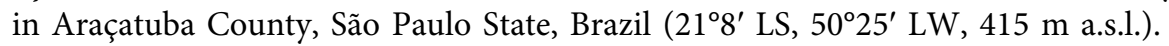

We used a Typic Ultisol (Santos et al. 2018) collected at 0-0.2 m depth with the following chemical attributes: Phosphorus $(\mathrm{P}$, resin $)=23 \mathrm{mg} \mathrm{kg}^{-1}$, soil organic matter $(\mathrm{SOM})=26 \mathrm{~g} \mathrm{~kg}^{-1}, \mathrm{pH}$ in $\mathrm{CaCl}_{2}=5.2$, potassium $\left(\mathrm{K}^{+}\right)=2.9 \mathrm{mmol}_{\mathrm{c}} \mathrm{kg}^{-1}$, calcium $\left(\mathrm{Ca}^{2+}\right)=25 \mathrm{mmol}_{\mathrm{c}} \mathrm{kg}^{-1}$, magnesium $\left(\mathrm{Mg}^{2+}\right)=17 \mathrm{mmol}_{\mathrm{c}} \mathrm{kg}^{-1}$, potential acidity $(\mathrm{H}+\mathrm{Al})=28 \mathrm{mmol}_{\mathrm{c}} \mathrm{kg}^{-1}$, cation exchange capacity $(\mathrm{CEC})=72.9 \mathrm{mmol}_{\mathrm{c}} \mathrm{kg}^{-1}$, and base saturation $(\mathrm{V})=62 \%$. Using an NFb culture in a semi-solid form, we estimated the population of diazotrophic microorganisms in the soil to be $9.5 \times 10^{4}$ bacteria $^{-1}$ of soil by the technique of the largest probable number, according to Döbereiner, Marriel, and Nery (1976).

The treatments were applied in a randomized complete block design with five replicates arranged in subdivided plots with repeated measures over time (three growth cycles). The treatments were determined based on the inoculation of plant growth promoting bacterial (PGPB) strains, including (i) Azospirillum brasilense CNPSo 2083 (Ab-V5) and CNPSo 2084 (Ab-V6), (ii) Pseudomonas fluorescens CNPSo 2719, and (iii) co-inoculation with Rhizobium tropici CIAT 899 and Azospirillum brasilense CNPSo 2084 (Ab-V6), each with the $\mathrm{N}$ application. In addition to the three treatments, we evaluated the effect of re-inoculation after each round of cutting, as well as two control treatments, one with the $\mathrm{N}$ application (positive control) and one without $\mathrm{N}$ fertilization and without inoculation (negative control), totaling eight treatments.

The inoculants concentration of each bacterial inoculant adjusted to $2 \times 10^{8}$ cells per $\mathrm{mL}$. The soil from each pot following nutrient addition consisted of the following: $\mathrm{Ca}\left(\mathrm{H}_{2} \mathrm{PO}_{4}\right)_{2}-200 \mathrm{mg}$ $\mathrm{kg}^{-1} \mathrm{P}, \mathrm{K}_{2} \mathrm{SO}_{4}-150 \mathrm{mg} \mathrm{kg}^{-1} \mathrm{~K}$ and $61 \mathrm{mg} \mathrm{kg}^{-1} \mathrm{~S}, \mathrm{H}_{3} \mathrm{BO}_{3}-0.5 \mathrm{mg} \mathrm{kg}^{-1} \mathrm{~B}, \mathrm{CuSO}_{4}-1.0 \mathrm{mg} \mathrm{kg}{ }^{-1}$ copper ( $\mathrm{Cu}$ ), $\mathrm{H}_{2} \mathrm{MoO}_{4}-0.1 \mathrm{mg} \mathrm{kg}{ }^{-1}$ molybdenum (Mo), $\mathrm{MnSO}_{4}-5.0 \mathrm{mg} \mathrm{kg}{ }^{-1}$ manganese (Mn), and $\mathrm{ZnSO}_{4}-2.0 \mathrm{mg} \mathrm{kg}{ }^{-1}$ zinc $(\mathrm{Zn})$. After four days, the 'Zuri' guinea grass was sowed. The 
bacterial inoculant concentrations were also estimated by counting colonies on solid NFb medium plates (Döbereiner, Marriel, and Nery 1976).

We used $15 \mathrm{~mL}$ of each inoculant for each kilogram $(\mathrm{kg})$ of seed before sowing. Seeds were dried for approximately $30 \mathrm{~min}$ in a cool and sun-sheltered location, after which they were seeded at 15 seeds per pot. The plants were thinned when they presented three fully expanded leaves, with five uniform plants maintained per pot. The plants were reinoculated by spraying a known volume $(300 \mathrm{~mL})$ after the first and second cuts, at which time the leaves began to develop again. A concentration of $4.0 \mathrm{~mL}$ of diluted inoculants in $296 \mathrm{~mL}$ water was used. Spraying was performed directly onto the plant leaves, with the sprayer filled to a volume sufficient to reinoculated all five pots corresponding to each treatment. $\mathrm{N}$ fertilization occurred via a solution from a graduated pipette four days before the forage was sown $\left(100 \mathrm{mg} \mathrm{dm}^{-3} \mathrm{~N}\right)$ and after second cuts $\left(100 \mathrm{mg} \mathrm{dm}{ }^{-3} \mathrm{~N}\right)$, for a total of $200 \mathrm{mg} \mathrm{dm}^{-3} \mathrm{~N}\left(\mathrm{NH}_{4} \mathrm{NO}_{3}\right)$.

\section{Plant harvest and measurements of productive and nutritional parameters}

Two weeks after the emergence of 'Zuri' guinea grass, thinning was performed to keep five uniform plants per pot. Deionized water was used for irrigation. The grass was evaluated when it reached an average height of $0.6 \mathrm{~m}$, and the plants were harvested down to $0.1 \mathrm{~m}$ above the surface of the ground. Three growth cycles with four-week intervals were evaluated. After each harvest, the material was identified, weighed and oven dried at approximately $65^{\circ} \mathrm{C}$ until it reached a constant weight.

The material was subsequently weighed on a precision balance to quantify the shoot dry weight (SDW) yield. After drying, the samples were ground in a Wiley type mill and the foliar nutrient concentration (N, P, K, Ca, Mg, S, B, Cu, Fe, Mn, and Zn) were determined according to Malavolta, Vitti, and Oliveira (1997). Crude protein was determined by multiplying $\mathrm{N}$ concentration by 6.25 . The acid detergent fiber (ADF) and neutral detergent fiber (NDF) concentration was determined according to Silva and Queiroz 2002).

On the day of each cutting took place, plant height readings were taken with a millimeter ruler. Immediately before each harvest, the relative chlorophyll index (RCI) was determined using a SPAD502 Plus chlorophyll meter (Spectrum technologies, Plainfield, IL, USA). The RCI values were obtained by the average of 10 readings performed in the middle third of newly expanded leaves (diagnostic leaves) of each experimental unit (Lavres Junior, Santos Junior, and Monteiro 2010). The number of tillers per pot were also counted. The collected plant material was first separated into tillers and main plants, and later the tiller mass per pot was determined. The material was then collected, and a second separation was performed on the grass leaves and stems to determine the mass of each component.

The roots were collected at the end of the experiment and washed in running water using 2-mm mesh sieves until all soil was removed. To determine the RDW yield the samples were properly identified, bagged, and the material was dried as described above. After drying in forced ventilation at approximately $65^{\circ} \mathrm{C}$ to a constant mass, all plant material collected during harvesting was weighed on a precision balance to quantify the RDW yield.

\section{Statistical analysis}

The data were tested for error normality and homogeneity of variances. The results were assessed using analysis of variance (ANOVA), F test $(p \leq 0.05)$ and compared using the Scott-Knott test with a $5 \%$ probability.

\section{Results and discussion}

\section{Shoot and roots dry weight yield}

There was a significant effect of the treatments on the SDW and RDW yield, considering the sum of the three cuttings. For the SDW yield, samples that received treatments with $\mathrm{N}$ fertilization had 
statistically higher yields relative to those in which $\mathrm{N}$ was not applied. The values varied between 26.0 and $51.2 \mathrm{~g}$ per pot for the control treatment without $\mathrm{N}$ or inoculation and the co-inoculation of R. tropici and A. brasilense (Ab-V6) plus re-inoculation, respectively, however, the accumulated SDW yield were $3.4 \%$ higher (Figure $1 \mathrm{a}, \mathrm{b}$ ).

For most of the evaluated parameters, the treatments in which the plants were inoculated with PGPB plus $\mathrm{N}$ fertilization had a similar performance than those that received only $\mathrm{N}$ fertilization (positive control). However, the use of PGPB increased the values evaluated relative to the positive control. The results showed that PGPB that they do promote greater $\mathrm{N}$ uptake and utilization
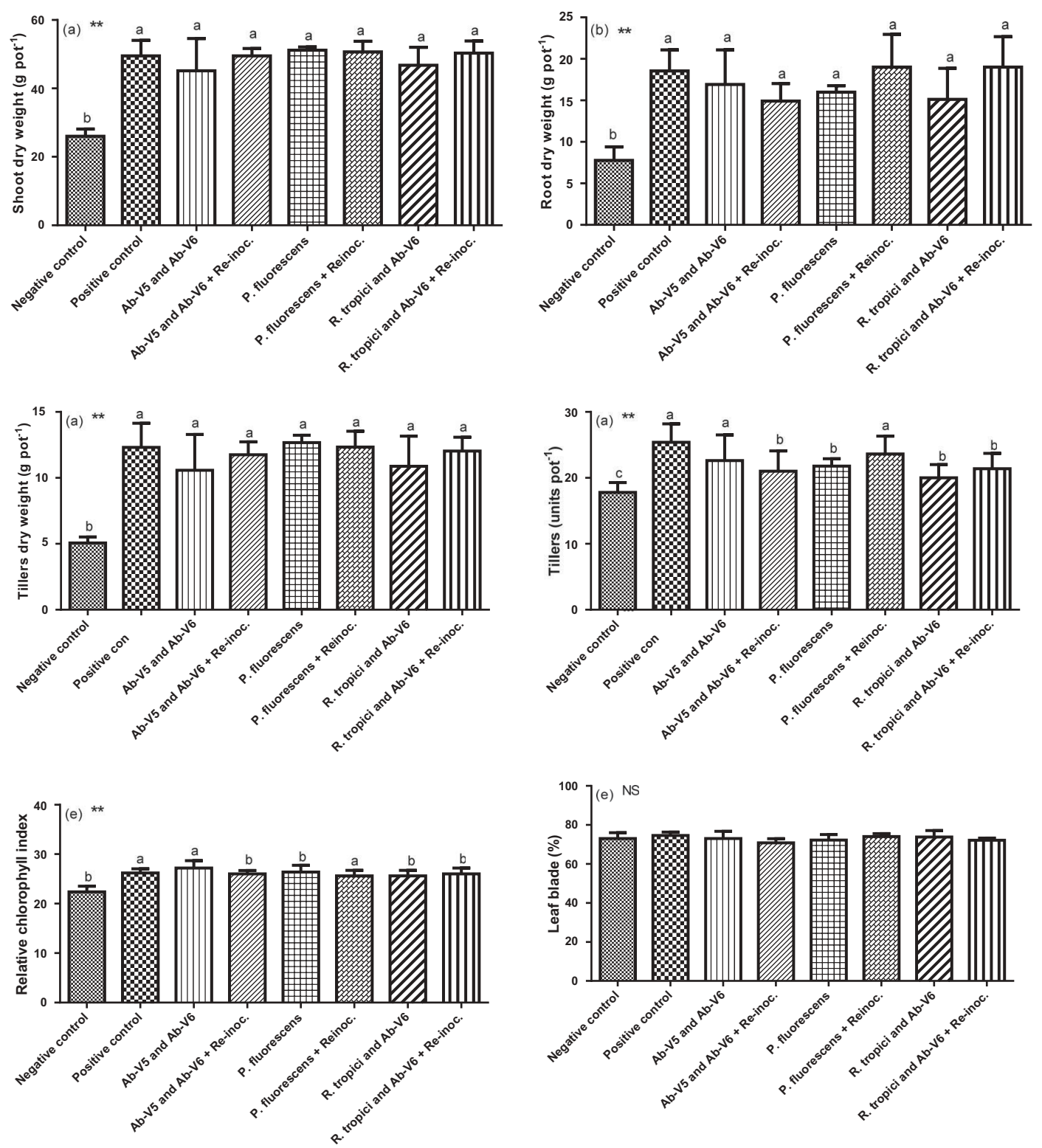

Figure 1. Shoot dry weight $\left(\mathrm{g} \mathrm{pot}^{-1}\right)$ (a) root dry weight $\left(\mathrm{g} \mathrm{pot}^{-1}\right)(\mathrm{b})$, tiller dry weight $\left(\mathrm{g} \mathrm{pot}^{-1}\right)(\mathrm{c})$, tillers (units pot $\left.{ }^{-1}\right)(\mathrm{d})$, relative chlorophyll index $(e)$, and leaf blade percentage $(f)$ in 'Zuri' guinea grass inoculated with PGPB. Error bars represent the mean standard error $(n=15)$. Means followed by letters differ for treatments, as determined by the Scott-Knott test $(P \leq 0.05)$. 
(Roesch et al. 2005; Saubidet, Fatta, and Barneix 2002), resulting in a synergistic effect between PGPB inoculation and $\mathrm{N}$ fertilization (Lana et al. 2012).

In general, there was a significant difference between inoculation with bacteria and the control treatments for most of the variables analyzed (Figure 1c-e). This fact can be related to the use of a suitable soil in terms of fertility, reducing the chances for more significant contrasting effects. However, PGPB promoted increases in yields when compared to the treatments without inoculation, as we observed positive effects of PGPB inoculation on the RDW and SDW yield, tiller yield, tiller units, RCI and overall height of 'Zuri' guinea grass plants. By contrast, PGPB inoculation presented was no significant results for leaf blade percentage (Figure 1f).

PGPB have the ability to promote growth and the availability of plant nutrients for BNF, to solubilize phosphate, to increase resistance, and to produce essential metabolites for growth (Shweta et al. 2014; Yang et al. 2014). One of the main phytonutrients synthesized by bacteria is indole3 -acetic acid (IAA), which promotes plant growth and increases the nutrients uptake, ensuring the efficient use of these resources (Hungria et al. 2010).

Brown (1972) found that the metabolites produced by PGPB, such as auxins, gibberellins and their precursors, influenced plant growth, as these substances are responsible for several physiological events that result in plant growth. Auxins and gibberellins act on the growth and elongation of stalks, leaves and roots, and induce changes in the expansion, division and cellular stretching of the meristematic regions, where plant growth occurs (Taiz and Zeiger 2013).

The main mechanisms of action of the genus Pseudomonas are the solubilization of phosphate, the increase in water absorption and the promotion of phytohormones (including IA) (Muleta et al. 2013). Criollo et al. (2012) studied the effect of inoculation with P. fluorescens on Pennisetum clandestinum verified higher shoot green weight yield by the plant compared to plants receiving only $\mathrm{N}$ fertilization and emphasized that such increases were the result of the release of phytohormones.

The co-inoculation of Azospirillum and Rhizobium is a technique widely used in legumes, especially common beans (Phaseolus vulgaris) and soybeans, consisting of the combination of different microorganisms that produce a synergistic effect, which tends to surpass the productive results obtained when these organisms are used in an isolated form (Hungria, Mendes, and Mercante 2013a). In Gramineae, strains of Azospirillum (Ab-V5 and Ab-V6) contribute as plant growth promoters (Hungria et al. 2010) to the yield and secretion of substances that promote better establishment and development of plants, including to the synthesis of IAA (Fukami et al. 2017a). By contrast, Rhizobium participates in BNF and phytohormone yields in non-legumes (García-Fraile et al. 2012). Certainly, this increase in yield is due to a series of products produced by the bacteria that are highly beneficial to the plant.

The results obtained here agree with those obtained by Aguirre et al. (2018) in which, when evaluating the yield of Coastcross-1 grass (Cynodon dactylon) inoculated with A. brasilense Ab-V5 and $\mathrm{Ab}-\mathrm{V} 6$ and fertilized with a $100 \mathrm{~kg} \mathrm{ha}^{-1} \mathrm{~N}$, they observed positive effects on SDW yield when compared to uninoculated controls. Hungria, Nogueira, and Araújo (2016) also observed beneficial effects on Urochloa spp. yield when combining strains of Ab-V5 and Ab-V6 and $40 \mathrm{~kg} \mathrm{ha}^{-1}$ of N, with the bacteria promoting increases from $17.4 \%$ to $29.6 \%$.

For the RDW yield, $\mathrm{N}$ fertilized treatments displayed statistically higher yields than those without $\mathrm{N}$ fertilizers (negative control). The highest productivity was with the co-inoculation of $R$. tropici and Ab-V6 with re-inoculation after each cutting and P. fluorescens. These plants had RDW yield of 19.0 g per pot, which was $2.2 \%$ higher than the positive control (Figure 1b). Although they were statistically similar, treatments re-inoculated with $R$. tropici and Ab-V6 and P. fluorescens displayed RDW yield increase of $25.8 \%$ and $18.8 \%$, respectively, relative to the co-inoculation of $R$. tropici and $\mathrm{Ab}-\mathrm{V} 6$ and P. fluorescens (Figure 1b).

Increases in RDW are also due to inoculation with PGPB. Cardenas et al. (2012) found that PGPB inoculation favored plant growth and nutrition and that these effects were due to a greater proliferation of root villi. Hernandez et al. (2001) justified that the adequate performance of A. brasilense in increasing root density and size was due to the greater availability of phytohormones, 
which result in a greater uptake of water and nutrients. Itzigsohn et al. (2000) reported that the inoculation of Azospirillum spp. in pastures has a beneficial potential, especially in regions with hydric deficits and low soil fertility, due to the larger root biomasses that result in a higher soil exploration capacity (Malik et al. 1997). This justifies the absence of significant results by the bacteria in the present study, since the soil used was chemically adequate and water was not a limiting factor.

Therefore, positive effects of PGPB inoculation on RDW and SDW yield of 'Zuri' guinea grass were observed, which promoted increases in yield when compared to treatments without inoculation, since the bacteria secrete substances, which increase root growth, plants have greater support and conditions for productivity and growth. The conduction of the pot experiment with sifted soil do not impose limits for the growth and development of the roots.

The greater development of roots allows better water and nutrient absorption, causing an increase in biomass yield and chlorophyll concentration, and promoting tolerance to environmental stress such as drought (Fukami, Cerezin, and Hungria 2018; Souza et al. 2017). In addition to these benefits, plant-growth-promoting bacteria can provide increased water retention in the soil through production of an extracellular matrix containing oligosaccharides and polysaccharides that increase water-retention capacity (Rubin, Van Groenigen, and Hungate 2017).

Increases in leaf and stem yield of forage plants results in higher SDW yield and, consequently, higher amounts of $\mathrm{C}$ are hijacked to increase the productivity and for storage in the soil via the roots. Well-managed forage plants with high biomass production can sequester a considerable amount of C (Cerri et al. 2010). Hungria, Nogueira, and Araújo (2016) reported the sequestration of $9.27 \mathrm{Mt}$ e$\mathrm{CO}_{2}$ in pasture areas inoculated with Azospirillum and destined for forage biomass yields.

Fukami et al. (2017b) evaluated the effects of inoculation with A. brasilense strains (Ab-V5 and $\mathrm{Ab}-\mathrm{V} 6)$ or the co-inoculation of R. tropici and Ab-V6 in corn (Zea mays L.), and found increases in the height and SDW yield of the plants relative to the control treatments without inoculation. The combination of bacterial species should be considered as an interesting alternative to combat saline stress in corn plants.

For the tiller dry weights, the highest productivity in the cuttings was in the plants inoculated together with $\mathrm{N}$ fertilization (Figure 1c). The dry weight was $12.7 \mathrm{~g}$ per pot, which represented an increase of $3.0 \%$ relative to the positive control, despite being statistically similar. For the units tiller, $\mathrm{Ab}-\mathrm{V} 5$ and Ab-V6 and $P$. fluorescens plus re-inoculation had higher values together with $\mathrm{N}$ fertilization (Figure 1d).

Increases in plant height and number of tillers in grasses inoculated with A. brasilense have been mainly attributed to the phytohormones production (Hungria, Nogueira, and Araújo 2016). Auxins, the main phytohormones released by $A$. brasilense to the host plants, promote root and shoot growth and have the capacity to regulate plant height (Dobbelaere, Vanderleyden, and Okon 2003; Fukami et al. 2017a; Taiz and Zeiger 2013). According to Souza et al. (2017), the auxin IAA (indole-3-acetic acid) promotes root growth and stimulates the differentiation in the meristematic tissues that depends on hormonal concentration. Among the benefits of Azospirullum, apparently IAA production is quantitatively the most important for grass growth (Fukami et al. 2017a).

For the relative chlorophyll index (RCI) of 'Zuri' guinea grass, the treatments the N-fertilized plants had RCI values that were statistically similar to each other and superior to those in which the plants were not fertilized with $\mathrm{N}$. There was no effect of re-inoculation after cuttings. The treatments in which plants were inoculated with PGPB and fertilized with $\mathrm{N}$ had higher RCI values relative to the unfertilized plants. According to Larcher (2000), the photosynthetic capacity is optimized with a higher $\mathrm{N}$ availability, as this nutrient is the main constituent of the chlorophyll molecule (Taiz and Zeiger 2013). Thus, the RCI can be used to predict the $\mathrm{N}$ concentration in plants by reading the amount of green pigments in the forage leaves. Guimarães et al. (2016) using the chlorophyll apparatus for RCI readings in U. brizantha cv. 'Marandu' inoculated with PGPB along three cuts, showed similar characteristics to the present study. They found that the first cutting presented the highest values, followed by the third and second cutting, with an average value for the A. brasilense inoculated treatment group of 27.4 RCI. 
The foliar re-inoculation did not present significant results for shoot and roots yields. These results are in agreement with Aguirre et al. (2018), who concluded that the re-inoculation of A. brasilense in Cynodum dactylum after the first year of cultivation was not necessary. Evaluating the agronomic response of triticale culture to different forms of Azospirillum strains application, Sipione et al. (2017) did not verify positive effects of leaf inoculation for height, stem dry weight and SDW. Galindo et al. (2015) evaluating the RCI of the irrigated wheat crop due to different application times of strains of $A$. brasilense via foliar, also did not find significant difference between the foliar inoculation and the control treatment.

There was no significant difference between the inoculation by the bacteria and the control treatments for most of the analyzed attributes. This fact can be related to the use of a suitable soil in terms of fertility and to the fact that the pots are watered daily, not presenting water limitation for plant growth, reducing the chances of more significant contrasting effects.

The results show that only PGPB do not substitute $\mathrm{N}$ fertilizers in grasses, but when associated, they promote greater N uptake and utilization (Saubidet, Fatta, and Barneix 2002). Lana et al. (2012) also reported synergism effect between inoculation and $\mathrm{N}$ fertilization.

\section{Shoot nutrients uptake}

The $\mathrm{N}, \mathrm{K}, \mathrm{Ca}$, and $\mathrm{Mg}$ concentration were significant as determined by an analysis of variance for the treatments (Figure 2a,c-e). As well as the morphological and productive components, the total $\mathrm{N}$ in SDW of the 'Zuri' guinea grass showed positive effects when the plants were inoculated with the PGPB, this is explained by the increase in the root volume and consequently the greater uptake of water and nutrients.

The nutrient that had the highest accumulations were total $\mathrm{N}$ and $\mathrm{K}$, result is due to the fact that nutrients are more absorbed and accumulated in the plant tissue (Boer et al. 2007; Torres et al. 2005). The $\mathrm{N}$ and $\mathrm{K}$ being an important structural nutrient in the functions of plants, participating in the biosynthesis of proteins and chlorophyll (Taiz and Zeiger 2013).

The increases in total $\mathrm{N}$ concentration and uptake had beneficial effects that were mainly due to the inoculation with the A. brasilense and Pseudomonas strains because of the organic compounds production that benefit root growth and enhance the water and nutrients uptake (Gupta, Dey, and Gupta 2013). In addition, the genus A. brasilense also carries out BNF, thus contributing to the better assimilation of available N. Bacteria of the genus A. brasilense can influence the activity of glutamine synthetase in grass roots, and this compound is extremely important in the $\mathrm{N}$ incorporation process and is essential for plants to express their full potential (Machado et al. 1998; Unno et al. 2006).

When evaluating the effects of inoculation with A. brasilense strains on U. brizantha and U. ruzizienses cultivars, Hungria, Nogueira, and Araújo (2016) and Leite et al. (2018) found significant effects of inoculation combined with $\mathrm{N}$ fertilization when compared to control treatments with only $\mathrm{N}$ fertilization. These data are similar to those found in the present study, although in spite of not having significant effects, the inoculation increased up to $8.8 \%$ the $\mathrm{N}$ accumulation.

The variation in $\mathrm{N}$ concentration of $2.3-12.6 \%$, higher to values found for U. brizantha (1.3-2.0) (Sousa and Lobato 2004). The inoculated plants showed a range of 3.0-126.6\% N, with the minimum value being slightly below adequate for the grass. However, use of stable isotopes $\left({ }^{15} \mathrm{~N}\right)$ would be necessary to confirm of BNF. We did not perform $15 \mathrm{~N}$ because we assumed that the main benefit of PGPB would be attributed the production of phytohormones (Hungria, Nogueira, and Araújo 2016).

The $\mathrm{N}$ fertilization together with inoculation was statistically similar to the positive control. Total $\mathrm{N}$ concentration and uptake in the shoots of 'Zuri' guinea grass. There was no difference between the plants that were reinoculated after the cuttings, but inoculation $P$. fluorescens increased up to $9.8 \%$ the $\mathrm{N}$ concentration. It should be noted that in the present study the nutrients concentration decreased over time with the cuttings, which is justified because the SDW yield of the forage plants also decreased over time with the cuttings, which consequently resulted in less nutrients uptake. 

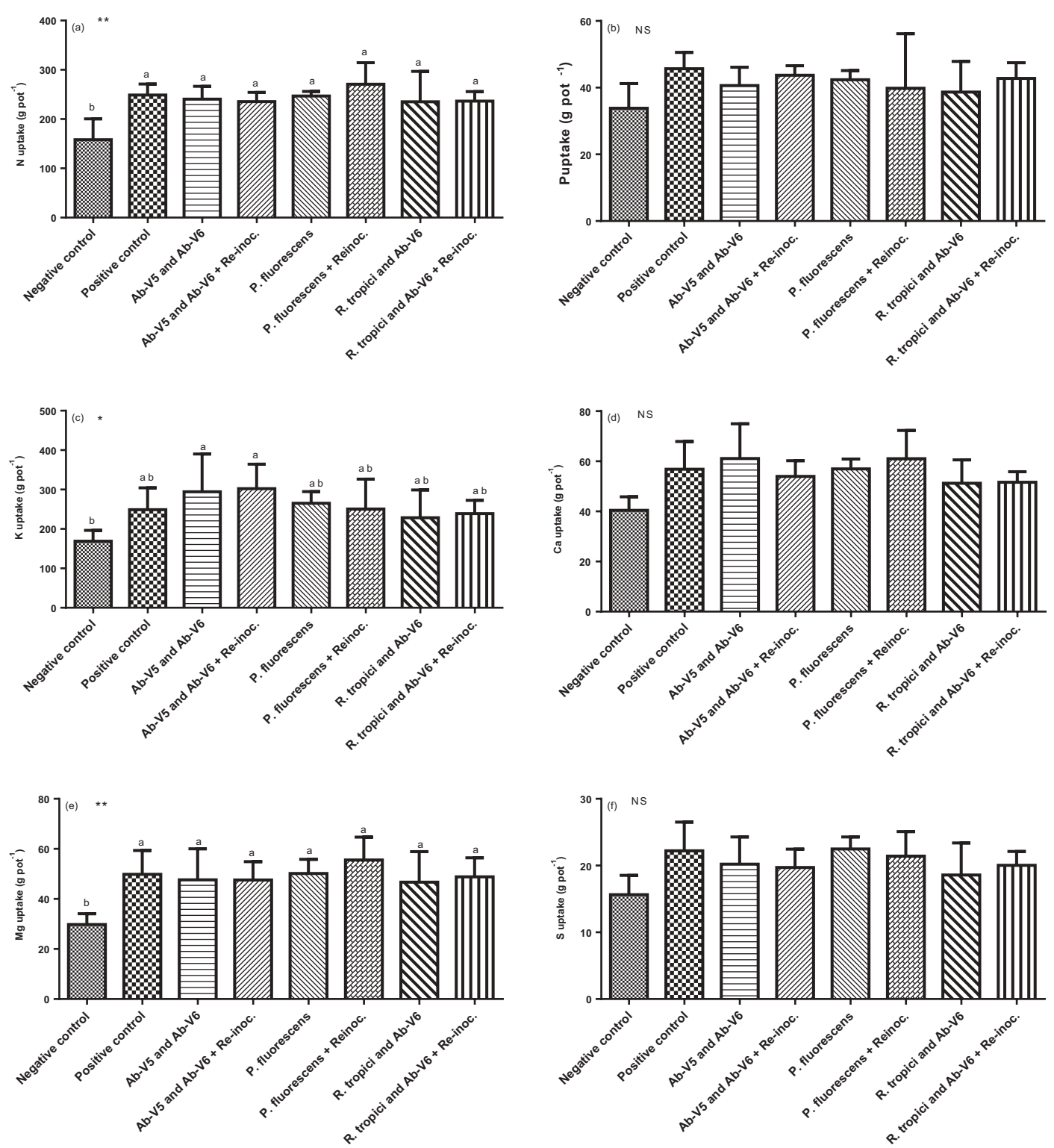

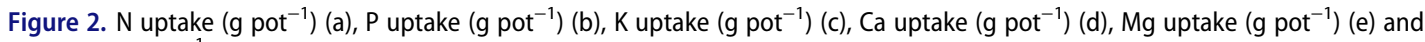
$S$ uptake $\left(g\right.$ pot $\left.^{-1}\right)$ ( $f$ ) in 'Zuri' guinea grass inoculated with PGPB. Error bars represent the mean standard error $(n=5)$. Means followed by letters differ for treatments, as determined by the Scott-Knott test $(P \leq 0.05)$.

Inoculation with plant growth-promoting bacteria when combined with inoculation with $\mathrm{N}$ fertilization, bacteria promoted increases in productivity, the relative chlorophyll index, shoot total $\mathrm{N}$ concentration and the uptake of 'Zuri' guinea grass. This result indicates that PGPB can be a sustainable alternative for reducing the use of $\mathrm{N}$ fertilizers. There were no effects of re-inoculation with $A$. brasilense, $P$. fluorescens or $R$. tropici on the nutrition or yield, demonstrating that these techniques still require further study to determine the correct form and period in which they should be performed.

Itzigsohn et al. (2000) evaluating the inoculation of native pastures with A. brasilense, concluded that the practice of inoculation with these bacteria has the potential to increase forage yield and reduce environmental damage caused by the fertilizers use. Similarly, from inoculation of 
A. brasilense on Coastcross grass (Cynodon dactylon), Aguirre et al. (2018) found an increase in forage yield and better pasture establishement. Overall, our results for M. maximus support the results of Aguirre et al. (2018).

The $\mathrm{P}$ concentration there were no significant differences in the treatments in which the plants were only inoculated with A. brasilense, P. fluorescens or R. tropici and Ab-V6, they increased the $\mathrm{P}$ concentration by 20,25 , and $14 \%$, respectively, relative to the negative control (Figure $2 \mathrm{~b}$ ). The present study demonstrated which the inoculation with $P$. fluorescens had the same $\mathrm{P}$ concentration. This contradicts the data of other authors, who justified because inoculation increases the available $\mathrm{P}$ through the mineralization of organic phosphates from phosphatases or the solubilization of inorganic phosphates and organic acids (Duijff, Gianinazzi-Pearson, and Lemanceau 1997). Vyas and Gulati (2009) observed that each strain of Pseudomonas secretes a different amount of organic acid, which directly influences phosphate solubilization and promotes plant growth.

The highest $\mathrm{K}$ concentration in SDW occurred in the treatments plants inoculated with A. brasilense with increase of $\mathrm{K}$ by $22 \%$ and $18 \%$, respectively, relative to the positive control (Figure 2c). The Mg concentration was also significant for the treatments. Additionally, the plants that were fertilized with $\mathrm{N}$ and inoculated with strains of $P$. fluorescens increased by $11.5 \%$ relative to the positive control (Figure 2e). Modesto et al. (2019) evaluating the effect of inoculation of A. brasilense on Urochloa brizantha in an irrigated area, in the macronutrient concentration verified smaller $\mathrm{K}, \mathrm{Mg}$, and $\mathrm{Ca}$ concentration when the plants were only inoculated in relation to the treatment with $\mathrm{N}$ fertilization.

The B and Mn concentration in SDW were significant (Figure 3a,d). The treatments in which the plants were inoculated with $P$. fluorescens showed the highest B accumulation, with $128 \mathrm{mg}$ per pot, which was a $25 \%$ increase in accumulation relative to the positive control. The Mn concentration in plants inoculated with $P$. fluorescens showed the highest of $\mathrm{Mn}$, with $592 \mathrm{mg}$ per pot, which was a $5.3 \%$ increase in accumulation relative to the positive control.

In general, the micronutrients concentration were positively affected when the plants were inoculated with PGPB. The bacteria significantly increased the B and Mn concentration relative to the control treatment with $\mathrm{N}$. Mn is an essential nutrient for the growth and development of plants, and it is related to the processes of respiration, enzymatic activation and the protection against oxidative stress (Buchel et al. 1999). According to Gray and Smith (2005), bacteria of the genus Pseudomonas can produce and secrete low molecular weight molecules, called siderophores that bind to Fe with a high affinity. These compounds bind to Fe are transported back to the microbial cell, and then the iron becomes available to the bacteria for growth (Dobbelaere, Vanderleyden, and Okon 2003).

Inoculation with plant growth-promoting bacteria when combined with inoculation with $\mathrm{N}$ fertilization, bacteria promoted increases in productivity, the relative chlorophyll index, and the uptake of $\mathrm{N}, \mathrm{K}, \mathrm{Ca}, \mathrm{Mg}, \mathrm{B}$, and $\mathrm{Mn}$ of 'Zuri' guinea grass. This result indicates that PGPB can be a sustainable alternative for reducing the use of $\mathrm{N}$ fertilizers. There were no effects of re-inoculation with A. brasilense, $P$. fluorescens or $R$. tropici on the nutrition or yield, demonstrating that these techniques still require further study to determine the correct form and period in which they should be performed. The benefits reported in our study suggest that the inoculation of pastures as a practice, in addition to reducing costs and increasing productivity, contributes to environmental sustainability.

\section{Nutritive value}

The percentages of crude protein (CP), neutral detergent soluble fiber (NDF), acid detergent soluble fiber (ADF) and shoot of 'Zuri' guinea grass presented significance in the analysis of variance for treatments (Figure $4 \mathrm{a}-\mathrm{c}$ ). The percentages of CP levels ranged from 8.2- to 11.2\%, and treatments with $\mathrm{N}$ fertilization and inoculated were statistically superior to non-fertilizers (Figure 4a). The NDF concentration ranged from 61.3- to $67.3 \%$ and ADF ranged from 30.3- to $34.1 \%$, and treatments without $\mathrm{N}$ fertilization and $\mathrm{Ab}-\mathrm{V} 5$ and $\mathrm{Ab}-\mathrm{V} 6+$ re-inoculation and $R$. tropici and $\mathrm{Ab}-\mathrm{V} 6$ were higher 

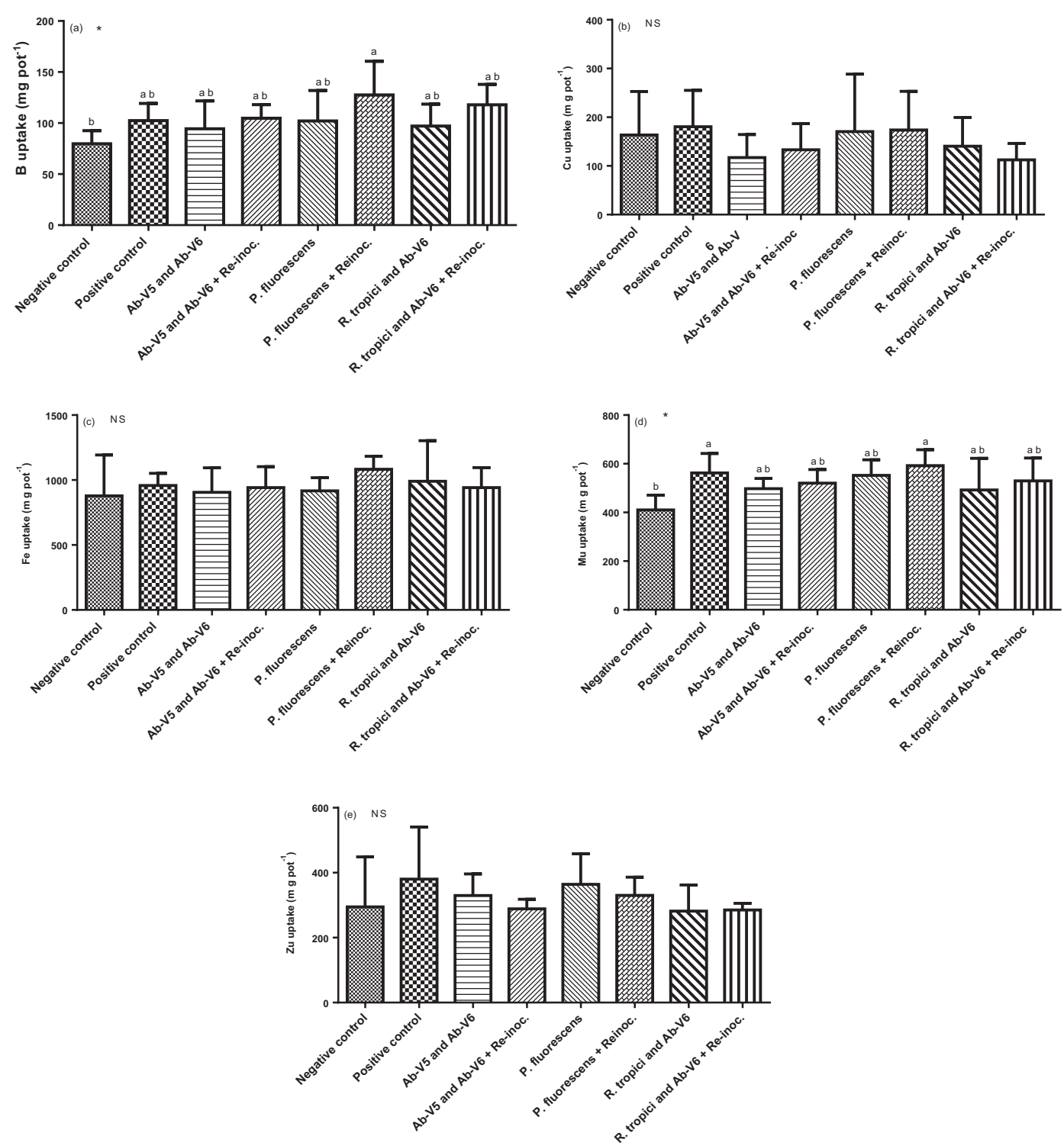

Figure 3. B uptake $\left(\mathrm{mg} \mathrm{pot}^{-1}\right)$ (a), Cu uptake $\left(\mathrm{mg} \mathrm{pot}^{-1}\right)$ (b), Fe uptake $\left(\mathrm{mg} \mathrm{pot}^{-1}\right)$ (c), Mn uptake (mg pot $\left.{ }^{-1}\right)(\mathrm{d})$ and $\mathrm{Zn}$ uptake $\left(\mathrm{mg} \mathrm{pot}^{-1}\right)$ (e) in 'Zuri' guinea grass inoculated with PGPB. Error bars represent the mean standard error $(n=5)$. Means followed by letters differ for treatments, as determined by the Scott-Knott test $(P \leq 0.05)$.

than the treatments that received $\mathrm{N}$ (Figure $4 \mathrm{~b}$ ). For the ADF concentration, the negative control and R. tropici and Ab-V6 were higher (Figure 4c).

Animal dry weight intake and digestibility are related to NDF and ADF. Thus the ADF indicates the percentage of highly indigestible material, so low ADF values indicate higher energy and high digestibility, and forages with low NDF content have a higher rate of consumption, thus, NDF contents higher than $60 \%$ in dry weight are harmful to consumption, with lower values being desirable (Moura et al. 2011). The NDF values of the present study were above $60 \%$, being in a range not recommended for an adequate rate in the consumption of animal fodder.

Evaluating the effect of inoculation by A. brasilense on seeds of $U$. brizantha associated with the use of N, Hanisch, Balbinot, and Vogt (2017) did not find significant effects of inoculation for the CP 

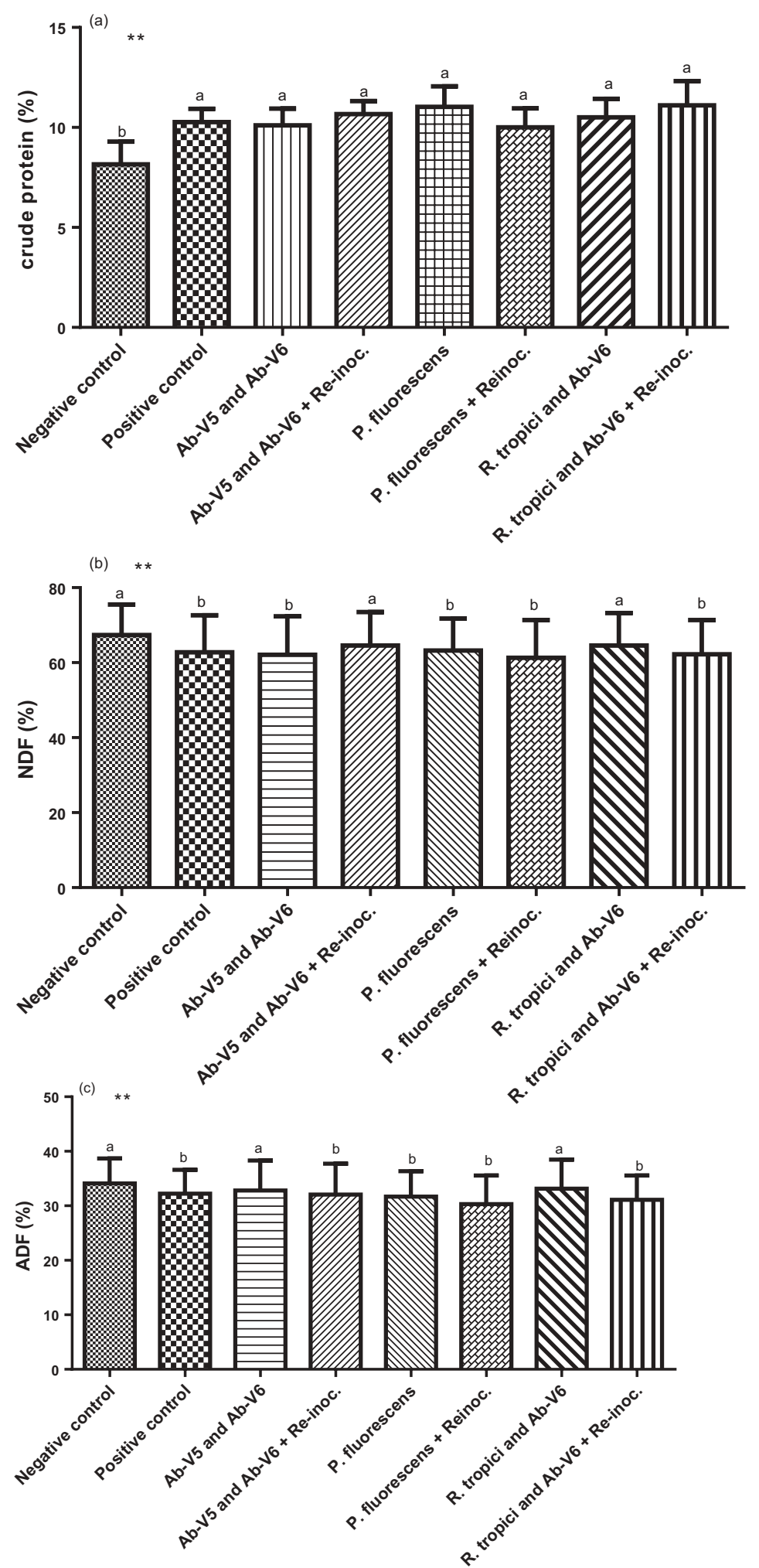

Figure 4. Crude protein (\%) (a), NDF (\%) (b) and ADF (\%) (c) in 'Zuri' guinea grass inoculated with PGPB. Error bars represent the mean standard error $(n=15)$. Means followed by letters differ for treatments, as determined by the Scott-Knott test $(P \leq 0.05)$. 
and NDF, presenting results similar to those of the present study. Bernd et al. (2014), when evaluating the effect of inoculation with $P$. fluorescens and $\mathrm{N}$ levels on the $\mathrm{CP}$ in maize, also did not verify significant effects of the inoculation, whether they were combined with $\mathrm{N}$ fertilization or not.

\section{Conclusion}

The plant growth-promoting bacteria and $\mathrm{N}$ fertilization promoted increases in SDW and RDW yield, tillers dry weight, RDI and nutrients uptake in shoots of 'Zuri' guinea grass (Megathyrsus maximus). There were effects of re-inoculation the PGPB by P. fluorescens shoot total $\mathrm{N}, \mathrm{Mg}$, and B uptake on shoot dry weight (SDW).

\section{Acknowledgments}

We would like to thank the Laboratory of Biotechnology of EMBRAPA Soja for providing the bacteria, the Foundation for Research Support of the State of São Paulo Process FAPESP Grant \#2017/17573-4 for financial aid to support this research for the support in conducting this work and for stock exchange financing (Process Grant \#2017/26364-0).

\section{References}

Aguirre, P. F., C. J. Olivo, P. F. Rodrigues, D. R. Falk, C. B. Adams, and H. P. Schiafino. 2018. Forage yield of Coastcross-1 pastures inoculated with Azospirillum brasilense. Acta Scientuarum, Animal Science 40:1-8.

Ardakani, M. R., D. Mazaheri, S. Mafakheri, and A. Moghaddam. 2011. Absorption efficiency of N, P, K through triple inoculation of wheat (Triticum aestivum L.) by Azospirillum brasilense, Streptomyces sp., Glomus intraradices and manure application. Physiology and Molecular Biology of Plants 17:181-92.

Bashan, Y., and L. E. De-Bashan. 2010. How the plant growth-promoting bacterium Azospirillum promotes plant growth-A critical assessment. Advances in Agronomy 108:77-136.

Bernd, L. P., T. M. Souza, M. A. Oliveira, E. Y. S. Ono, C. Zucareli, and E. Y. Hirooka. 2014. Inoculation of Pseudomonas fluorescens and NPK fertilization chemical composition and fungal-fumonisin contamination of maize. Revista Brasileira De Engenharia Agrícola E Ambiental 18:1274-80.

Boer, C. A., R. L. Assis, G. P. Silva, A. J. Braz, A. L. Barroso, A. Cargnelutti Filho, and F. R. Pires. 2007. Nutrient cycling in off-season cover crops on a Brazilian savanna soil. Pesquisa Agropecuária Brasileira 42:1269-76.

Bottini, R., M. Fulchieri, D. Pearce, and R. P. Pharis. 1989. Identification of gibberellins A1, A3, and iso-A3 in cultures of Azospirillum lipoferum. Plant Physiology 90:45-47.

Brown, M. E. 1972. Plant growth substances produced by microorganisms of soil and rhizosphere. Journal of Applied | bacteriology 35:443-51.

Buchel, C., J. Barber, G. Ananyev, S. Eshaghi, R. Watt, and C. Dismuke. 1999. Photoassembley of the manganese cluster and oxygen evolution from monomeric and dimeric CP47-reaction center photosystem II complexes. Proceedings of the National Academy of Science 96:14288-93.

Cardenas, A., R. L. Rodriguez, V. Pizarro, L. F. Cadavid, and C. Arevalo-Ferro. 2012. Shifts in bacterial communities of two Caribbean reef-building coral species affected by white plague disease. ISME Journal 6:502-12.

Cerri, C. C., M. Bernoux, S. M. F. Maia, C. E. P. Cerri, C. Costa Junior, B. J. Feigl, L. A. Frazão, F. F. C. Mello, M. V. Galdos, C. S. Moreira, et al. 2010. Greenhouse gas mitigation options in Brazil for land-use change, livestock and agriculture. Scientia Agricola 67:102-16.

Criollo, P., M. Obando, L. Sánchez, and R. Bonilla. 2012. Efecto de bacterias promotoras del crecimiento vegetal (PGPR) asociadas a Pennisetum clandestinum en el altiplano cundiboyacensell. Revista Corpoica - Ciencia Y Tecnologia Agropecuaria 13:189-95.

Dobbelaere, S., J. Vanderleyden, and Y. Okon. 2003. Plant growth-promoting effects of diazotrophs in the rhizosphere. Critical Review in Plants Science 22:107-49.

Döbereiner, J., I. Marriel, and M. Nery. 1976. Ecological distribution of Spirillum lipoferum. Canadian Journal of Microbiology 22:1464-73.

Duijff, B. J., V. Gianinazzi-Pearson, and P. Lemanceau. 1997. Involvement of the outer membrane lipo polysaccharides in the endophytic colonization of tomato roots by biocontrol Pseudomonas fluorescens strain WCS417r. New Phytologist 135:325-34.

Fukami, J., C. Osa, F. J. Ollero, M. Megías, and M. Hungria. 2017b. Co-inoculation of maize with Azospirillum brasilense and Rhizobium tropici as a strategy to mitigate salinity stress. Functional Plant Biology 45:328-39. 
Fukami, J., F. J. Ollero, M. Megías, and M. Hungria. 2017a. Phytohormones and induction of plant-stress tolerance and defense genes by seed and foliar inoculation with Azospirillum brasilense cells and metabolites promote maize growth. $A M B$ Express 7:153-66.

Fukami, J., P. Cerezin, and M. Hungria. 2018. Azospirillum: Benefits that for far beyond biological nitrogen fixation. AMB Express 8:73.

Galindo, F. S., M. G. Z. Ludkiewicz, J. L. M. Bellote, J. M. K. Santini, C. J. Alves, and M. C. M. Teixeira Filho. 2015. Effect of leaf application times of Azospirillum brasilense in the nutrients level of wheat irrigated. Revista Tecnologia E Ciência Agropecuária 9:37-42.

García-Fraile, P., L. Carro, M. Robledo, M. H. Ramírez-Bahena, J. D. Flores-Félix, M. T. Fernández, P. F. Mateos, R. Rivas, J. M. Igual, E. Martínez-Molina, et al. 2012. Rhizobium promotes non-legumes growth and quality in several production steps: Towards a biofertilization of edible raw vegetables healthy for humans. PLoS One 7: e38122.

Gray, E. J., and D. L. Smith. 2005. Intracellular and extracellular PGPR: Commonalities and distinctions in the plant-bacterium signaling processes. Soil Biology Biochemical 37:395-412.

Guimarães, S. L., C. S. A. Santos, E. M. Bonfim-Silva, A. C. Polizel, and E. R. Batista. 2016. Nutritional characteristics of marandu grass (Brachiaria brizantha cv. marandu) subjected to inoculation with associative diazotrophic bacteria. African Journal of Microbiology Research 10:873-82.

Gupta, K., A. Dey, and B. Gupta. 2013. Plant polyamines in abiotic stress responses. Acta Physiol Plant 35:2015-36.

Hanisch, A. L., A. A. Balbinot Jr, and G. A. Vogt. 2017. Productive performance of Urochloa brizantha cv. Marandu as a function of inoculation with Azospirillum and nitrogen doses. Revista Agroambiente 11:200-08.

Hernandez, J. A., M. A. Ferrer, A. Jimenez, A. R. Barcelo, and F. Sevilla. 2001. Antioxidant systems and $\mathrm{O}_{2} / \mathrm{H}_{2} \mathrm{O}_{2}$ production in the apoplast of pea leaves. Its relation with salt-induced necrotic lesions in minor veins. Plant Physiology 27:827-31.

Hungria, M., I. C. Mendes, and F. M. Mercante. 2013a. Biological nitrogen fixation as low carbon technology for common bean and soybean crops. Londrina, Brazil: Embrapa Soja.

Hungria, M., M. A. Nogueira, and R. S. Araújo. 2013b. Co-inoculation of soybeans and common beans with rhizobia and azospirilla: Strategies to improve sustainability. Biology Fertility Soils 49:791-801.

Hungria, M., M. A. Nogueira, and R. S. Araújo. 2016. Inoculation of Brachiaria spp. with the plant growth-promoting bacterium Azospirillum brasilense: An environment-friendly component in the reclamation of degraded pastures in the tropics. Agriculture, Ecosystems and Environment 221:125-31.

Hungria, M., R. J. Campo, E. M. Souza, and F. O. Pedrosa. 2010. Inoculation with selected strains of Azospirillum brasilense and A. lipoferum improves yields of maize and wheat in Brazil. Plant and Soil 331:413-25.

Itzigsohn, R., S. Burdman, Y. Okon, E. Zaady, R. Yonatan, and A. Perevolotsky. 2000. Plant-growth promotion in natural pastures by inoculation with Azospirillum brasilense under suboptimal growth conditions. Arid Soil Researchand Rehabilitation 14:151-58.

Lana, M. C., J. Dartora, D. Marini, and J. E. Hann. 2012. Inoculation with Azospirillum, associated with nitrogen fertilization in maize. Revista Ceres 59:399-405.

Larcher, W. 2000. Plant ecophysiology. São Carlos, Brazil: Editora Rima.

Lavres Junior, J., D. G. Santos Junior, and F. A. Monteiro. 2010. Nitrate reductase activity and SPAD readings in leaf tissues of guinea grass submitted to nitrogen and potassium rates. Revista Brasileira De Ciência Do Solo 34:801-09.

Leite, R. C., J. G. D. Santos, E. L. Silva, C. R. C. R. Alves, M. Hungria, R. C. Leite, and A. C. Santos. 2018. Productivity increase, reduction of nitrogen fertiliser use and drought-stress mitigation by inoculation of Marandu grass (Urochloa brizantha) with. Azospirillum Brasilense. Crop \& Pasture Science 70:61-67.

Machado, A. T., L. Sodek, J. Döbereiner, and V. M. Reis. 1998. Evaluation of nitrogen fertilizer and inoculation with diazotrophic bacteria on the biochemical behavior of the maize cultivar nitroflint. Pesquisa Agropecuária Brasileira 33:961-70.

Malavolta, E., G. C. Vitti, and S. A. Oliveira. 1997. Evaluation of nutritional status of plants: Principles and applications [Avaliação do estado nutricional das plantas: Princípios e aplicações]. Piracicaba, Brazil: Potafos.

Malik, K. A., R. Bilal, S. Mehnaz, G. Rasul, M. S. Mirsa, and M. S. Ali. 1997. Association of nitrogen-fixing, plant-growth-promoting rhizobacteria (PGPR) with kallar grass and rice. Plant and Soil 194:37-44.

Modesto, V. C., M. Andreotti, O. J. Sabbag, D. A. Soares, E. A. P. Pechoto, I. M. Pascoaloto, and A. M. Nakao. 2019. Economic analysis of the corn intercropped with Marandu grass as a function of Azospirillum brasilense application. Journal of Agricultural Science 11:387-95.

Moura, R. L., M. P. S. C. B. Nascimento, M. M. Rodrigues, M. E. Oliveira, and J. B. Lopes. 2011. Leaf-to-stem ratio and bromatological characteristics of Campo Grande stylo regrowth at five cutting ages. Acta Scientiarum Sciences 33:2492-53.

Muleta, D., F. Assefa, E. Börjesson, and U. Granhall. 2013. Phosphate-solubilising rhizobacteria associated with Coffea arabica L. in natural coffee forests of southwestern Ethiopia. Journal of the Saudi Society of Agricultural Sciences 12:73-84.

Rodriguez, H., T. Gonzalez, I. Goire, and Y. Bashan. 2004. Gluconic acid production and phosphate solubilization by the plant growth-promoting bacterium Azospirillum spp. Naturwissenschaften 91:552-55. 
Roesch, L. F., F. O. Camargo, P. A. Selbach, and E. S. Sá. 2005. Reinoculation of diazotrophic bacteria improving growth of wheat. Ciência Rural 35:1201-04.

Rubin, R. L., K. J. Van Groenigen, and B. A. Hungate. 2017. Plant growth promoting rhizobacteria are more effective under drought: A meta-analysis. Plant and Soil 416:309-23.

Sá, G. C. R., C. L. M. Carvalho, A. Moreira, M. Hungria, M. A. Nogueira, R. Heinrichs, and C. V. Soares Filho. 2019. Biomass yield, nitrogen accumulation and nutritive of Mavuno grass inoculated with plant growth-promoting bacteria. Communications in Soil Science and Plant Analysis 50:1931-42.

Sahoo, R. K., M. W. Ansari, M. Pradhan, T. K. Dangar, S. Mohanty, and N. Tuteja. 2014. Phenotypic and molecular characterization of native Azospirillum strains from rice fields to improve crop productivity. Protoplasma 251:943-53.

Santos, H. G., P. K. T. Jacomine, L. H. C. Anjos, V. A. Oliveira, J. F. Lumbreras, M. R. Coelho, J. A. Almeida, J. C. Araujo Filho, J. B. Oliveira, and T. J. F. Cunha. 2018. Brazilian system of soil classification. Brasília, Brazil: Embrapa Informação Tecnológica.

Saubidet, M. I., N. Fatta, and A. J. Barneix. 2002. The effect of inoculation with Azospirillum brasilense on growth and nitrogen utilization by wheat plants. Plant and Soil 245:215-22.

Shweta, S., M. B. Shivanna, B. R. Gurumurthy, R. Uma Shaanker, T. R. Santhosh Kumar, and G. Ravikanthet. 2014. Inhibition of fungal endophytes by camptothecine produced by their host plant, Nothapodytes nimmoniana (Grahm) Mabb. (Icacinaceae). Current Science 107:994-1000.

Silva, D. J., and A. C. Queiroz. 2002. Análise de alimentos: Métodos químicos e biológicos. 3 ed. Viçosa, Brazil: Universidade Federal de Viçosa.

Sipione, M. S., A. C. Limede, C. E. S. Oliveira, A. Zoz, C. S. Silva, and T. Zoz. 2017. Ways of inoculation of Azospirillum brasilense in the initial growth of triticale. Revista Scientia Agraria 18:86-94.

Sousa, D. M. G., and E. Lobato. 2004. Cerrado: Correção do solo e adubação. Brasília, Brazil: Embrapa Informação Tecnológica.

Souza, M. S. T., V. A. Baura, S. A. Santos, P. I. Fernandes-Júnior, F. B. Reis Junior, M. R. Marques, G. M. Paggi, and B. M. Silva. 2017. Azospirillum spp. from native forage grasses in Brazilian pantanal floodplain: Biodiversity and plant growth promotion potential. World Journal of Microbiology \& Biotechnology 33:81.

Spaepen, S., and J. Vanderleyden. 2015. Auxin signaling in Azospirillum brasilense: A proteome analysis. In Biological nitrogen fixation, ed. F. J. Brujin, 937-40. Hoboken: Wiley.

Taiz, L., and E. Zeiger. 2013. Plant physiology. Porto Alegre, Brazil: Artemed.

Teixeira, N. M., R. Heinrichs, C. S. B. Bonini, J. Afzal, G. C. Meirelles, C. V. Soares Filho, and A. Moreira. 2019. Chelated zinc leaf application on nutrients concentration and yield of Mombasa grass. Journal of Plant Nutrition 42:89-98.

Tien, T. M., M. H. Gaskins, and D. H. Hubbell. 1979. Plant growth substances produced by Azospirillum brasilense and their effect on the growth of Pearl Millet (Pennisetum americanum L.). Applied and Environmental Microbiology 37:1016-24.

Torres, J. L., M. G. Pereira, I. Andrioli, J. C. Polidoro, and A. J. Fabian. 2005. Cover crops residue decomposition and nitrogen release in a Cerrado soil. Revista Brasileira De Ciência Do Solo 29:609-18.

Unno, H., T. Uchida, H. Sugawara, L. Kurisu, T. Sugyiama, G. Kurisu, T. Sugiyama, T. Yamaya, H. Sakakibara, T. Hase, et al. 2006. Atomic structure of plant glutamine synthetase. The Journal of Biological Chemistry 281:29287-96.

Volpe, V., W. Chitarra, P. Cascone, M. G. Volpe, P. Bartolini, G. Moneti, G. Pieraccini, C. Di Serio, B. Maserti, E. Guerrieri and R. Balestrini. 2018. The association with two different arbuscular mycorrhizal fungi differently affects water stress tolerance in tomato. Frontiers in Plant Science 9:1-16.

Vyas, P., and A. Gulati. 2009. Organic acid production in vitro and plant growth promotion in maize under control and environment by phosphate-solubilizing Pseudomonas. fluorescens. BMC Microbiology 9:1-15.

Yang, Y., H. Zhao, R. A. Barrero, B. Zhang, G. Sun, I. W. Wilson, F. Xie, K. D. Walker, J. W. Parks, R. Bruce, et al. 2014. Genome sequencing and analysis of the paclitaxel-producing endophytic fungus Penicillium aurantiogriseum NRRL 62431. BMC Genomics 15:197. 